\title{
Role of Working Conditions on Organization Citizenship Behaviour in the Banking Industry: A Survey of Barclays Bank in North Rift Region
}

\author{
James Ngugi \\ PHD Student, School of human resource and Development, Moi University, Kenya
}

\begin{abstract}
Organizational citizenship behavior $(O C B)$ is an employee behavior in which the purpose is to increase the efficiency of company performances. The dimension of OCB based on Organ et al (2006) include altruism, conscientiousness, sportsmanship, courtesy and civic virtue. The purpose of this study was to find out the role of working conditions on organization citizenship behaviour in the banking industry. The study targeted a total population of 220 employees in Barclays Bank North Rift region. To determine the sample size, a formula by Kathuri and Pals (1993) was used to get a sample size of 120 respondents. Data was collected using questionnaires and analyzed using descriptive statistics and inferential statistics. Descriptive statistics used included frequencies, percentages and means while the inferential statistics used was multiple regression. The findings show that working conditions was significant in explaining organizational citizenship behavior. It was thus recommended that Barclays bank should ensure good working conditions at the workplace which would increase the degree of job satisfaction also effectual human resource management and preserving progressive work environment would be consequence the job satisfaction and performance of organization as well as entire economy. Further research is also required to study the factors determining employee organizational citizenship behavior in Kenya. This will help to solve problems that surround employee organizational citizenship behavior.
\end{abstract} Key Words: Working Conditions and Organization Citizenship Behaviour

\section{Introduction}

Organization Citizenship Behavior refers to employee behavior that is discretionary, not directly recognized by the formal reward system, it promotes the effective functioning of the organization (Organ \& Dennis, 2006). OCB provides a means of managing the interdependencies among members of a work unit, which increases the collective outcome achieved; reduces the need for an organization to allocate scarce resources to simple maintenance functions, which frees up resources for productivity and promotes the ability of others to perform their jobs by efficient planning, scheduling and ensuring that they solve problems (Podsakoff et al., 2000). Employee organizational citizenship behaviors are work behaviors that are defined as individual behaviors beneficial to organizations, not directly recognized by the formal reward system. Organizational Citizenship Behaviors are thought to have an important impact on the effectiveness and efficiency of work teams and organizations, therefore contributing to the overall organizational productivity (Cannel, 2008).

According to Central Bank of Kenya annual report (2012), commercial banks in Kenya have a great disparity in their remuneration system depending on the compensation philosophy. There is uniformity on timing as all banks remit employee salaries on the twenty fifty day of every month. Barclays Bank has operated in Kenya for over 90 years. Financial Strength coupled with extensive local and international resources have positioned Barclays Bank of Kenya as a fore most provider of financial services. Barclays bank has established an extensive network of 120 outlets with over 230 ATMs spread across the country. The Barclays Bank network is supported by Internet and mobile banking channels plus a Customer Service Centre that operates 24 hours a day, 7 days a week (Barclays Bank of Kenya, 2015).

Over the past two years, Barclays Bank has undertaken a complete change in its core banking system. This involved changing the entire operating system across its branches in the country. The process involved setting up a complete project team with a change director at the helm of the project. The main aim was to improve on the efficiency of services provided to the customer and to reduce its operating costs hence setting it apart from their competitors as the bank of choice. Business organizations, especially the banking industry of the $21^{\text {st }}$ century operates in a competitive environment with changing conditions and unpredictable economic climate (Barclays bank of Kenya, 2015).

\subsection{The Statement of the Problem}

Due to the dynamism of technology, pressure to achieve organizational objectives/goals, need to improve organizational performance, control of operational costs and curb wastage, there is therefore great need 
to improve on employee organizational citizenship behavior in the banking industry (Bennett, et al, 2000). According to Benjamin (2012), the world-wide competition, increases the importance of organizational citizenship behavior as a means for effective management of human resources, as well as enhancing organizational viability.

Many financial institutions have been registered in Kenya since independence. This has led to stiff competition in the industry. All these financial institutions are competing for the same customers. This therefore calls for exemplary service in order to attract and retain the current customers it is therefore imperative for institutions to be innovative and creative to win the customer's trust and loyalty. Barclays bank spends billions of money each year trying to motivate or reward its employees, but these interventions do not always translate into higher levels of employee motivation thus there is need for introduction of non monetary incentives in the bank.. Despite these interventions taken by Barclays bank, employees and managers give different levels of importance to various motivational rewards depending on the situation; however an employee still have low morale and performs below the expectation of the organization. This research therefore aimed at finding out the role of working conditions on organization citizenship behaviour in the banking industry.

\subsection{Working Conditions and Employee Organizational Citizenship Behaviour}

The effect of organizational structure and its environment on the employee organizational citizenship behaviour of its members has been an important issue of analysis (Arul, 2009). In industrial context, the problem of increasing production and making the work environment more conducive have been approached through the introduction of durable changes in working environment. According to Becker (2003) during early days of development of industrial psychology only physical environment in work place was given importance and was considered as a predominant determinant of employees' productivity. Earlier studies examined the effect of illumination, temperature, noise, and atmospheric conditions on productivity of employees. However, no consistent relationship could be established between these components of physical work environment and performance. After Hawthorne studies industrial psychologists started shifting their attention to the study of social and psychological environment and its effects on employee organizational citizenship behavior, The recognition of the significant role of psycho-social environment led to the emergence of organizational psychology, and furthers the concept of quality of work life. The importance of physical work environment has now been realized. Further modern organizations are making all possible efforts to ensure work environment is more comfortable, safe and healthy, which led to the emergence of a new branch of organizational psychology, known as occupational health psychology. This is a psychological method of looking holistically at the work environment and employee health. Occupational health psychology looks at employees' health as well as the organizational health in a synergistic relationship on employee organizational citizenship behaviour, and tries to understand the dynamic interaction (Benjamin, 2012).

Bernstein et al (2011) did a study to examine the effect of physical work environment and organizational climate on employees' job satisfaction, performance, and health. the study found that these conditions improves employee organizational citizenship behaviour Scott, Jusanne and Steven (2000) reported that working conditions are associated with employees' job involvement and job satisfaction. Christina, Stamper \& Lyn (2003) in a study observed that social, employee organizational citizenship behaviour, organizational and physical context serve as the impetus for tasks and activities, and considerably influence employees' performance, output and production. According to Benjamin (2012), the influence of organizational climate, which is composed of organizational, social and psychological factors, has been extensively examined. This shows that, employees' motivation, job satisfaction, job involvement, job performance and employee health have been found to be influenced by employee organizational citizenship behavior.

$\mathrm{H}_{\mathrm{O} 1}$ : There is no relationship between working conditions and organization citizenship behaviour in the banking industry

\section{Materials And Methods}

This study adopted a descriptive survey design. The target population of the study included employees of Barclays north rift region, Eldoret branch with 85 employees, Kitale branch with 30 employees, Kabarnet branch with 30 employees, Kapsabet with 30 employees, Kapenguria with 20 employees and Webuye with 25 employees. The study used 5-point likert questionnaires as data collection instruments. The Cronbach's coefficient alpha was applied on the results obtained to determine how items correlate in the same instrument. Cronbach's coefficient Alpha of more than 0.7 was taken as the cut off value for being acceptable which enhanced the identification of the dispensable variables and deleted variables. Data was analyzed using descriptive statistics and inferential statistics. Descriptive statistics used included frequencies, percentages and means while the inferential statistics used was multiple regression. 


\section{Results And Discussion}

4.1 Working Condition and Organization Citizenship Behaviour

The study sought to establish the role of working condition on organization citizenship behaviour

Table 4.0: Working Condition and Organization Citizenship Behaviour

\begin{tabular}{|l|r|r|}
\hline Working Condition & M & SD \\
\hline There is conducive environment for work & 4.580 & .538 \\
\hline Health and safety is prioritized in the work place & 3.989 & .759 \\
\hline Stress management is addressed in the work place & 4.000 & .766 \\
\hline Working conditions facilitates employee relations. & 4.440 & .499 \\
\hline $\begin{array}{l}\text { Working conditions illumination, temperature, noise, and atmospheric conditions affects } \\
\text { productivity of the workers }\end{array}$ & 4.710 & .456 \\
\hline Working conditions has facilitated quality of work & 4.505 & .503 \\
\hline Working conditions has facilitated work Life balance & 3.968 & .667 \\
\hline Working conditions has facilitated a typical and precarious working environment & 4.559 & .521 \\
\hline
\end{tabular}

From the questionnaire the study sought to find out the role of Working Condition on Organization Citizenship Behaviour, The results showed the responses were supported by a mean score of 4.580, and it was spread from the mean at standard deviation of 0.538 . The finding that health and safety is prioritized in the respondents work place showed that the results had a mean score of 3.989 which was spread from the mean at standard deviation of 0.759.This indicates that health and safety in institutions is a predictor of organizational citizenship behaviour

The results on the issue that Stress management is addressed in the respondents work place was supported by a mean of 4.000 , this result was spread from the mean at 0.766 which implies a positive relationship between stress management and organizational citizenship behavior in organizations. From the results on the issue that working conditions facilitates employee relations, shows that $70.9 \%$ of the respondents agreed with a mean of 4.440 which is spread at a standard deviation of 0.499 . The result that Working conditions illumination, temperature, noise, and atmospheric conditions on productivity of the workers affects organization citizenship behavior was supported by an agreement rate at a mean of 4.710 which is spread at standard deviation of 0.456 . The response that working conditions has facilitated quality of work in organizations leading to organizations citizenship behavior was supported by an agreement rate at a mean of 4.505 which is spread at standard deviation of 0.503 . Further the result that working conditions has facilitated work life balance was supported by a mean of 3.733 which is spread at a standard deviation of 0.742 .

Lastly the respondents agreed that working conditions has facilitated a typical and precarious working in their organization with a mean score of the responses was 4.559.This indicates a higher level of agreement on the questionnaire statements. The responses were also spread from the mean at a 0.521 standard deviation. From the results, the overall mean score of 4.019 which means that more respondents were agreeing with the questionnaires statement on the role of working condition on organizational citizenship behavior. In addition the responses were spread from the mean at 1.503 standard deviation These results support that of Scott, Jusanne and Steven (2000) who reported that working conditions are associated with employees' job involvement and job satisfaction. It also supports that of Strong, Jeannerert, Blackley and McPhail (2009) who stated that social, employee organizations citizenship behaviour, organizational and physical context serve as the impetus for tasks and activities, and considerably influence workers' performance and work output. Finally the study supports the findings of Dugdill (2000), who observed that employees' motivation, job satisfaction, job involvement, job performance, and health are influenced by employee organizational citizenship behavior. The effect of organizational structure and its environment on the employee organizational citizenship behaviour of its members has been an important issue of discussion and analysis since long back (Arul, 2009). In industrial context, the problem of increasing production and making the work environment more pleasant have been approached through the introduction of durable changes in working environment.

\subsection{Inferential Statistics}

\subsection{Assumption of Linearity}

From the study Pearson product moment correlation was used to assess the linearity among the variables of the study (working conditions and organizational citizenship behavior) From the results in table 4.1 there was positive relationship between the dependent and independent variables of the study thus assumption of linearity was supported

Table 4.1: Assumption of Linearity

\begin{tabular}{|l|l|l|l|}
\hline \multicolumn{2}{|c|}{} & W C & OCB \\
\hline W C & Pearson Correlation & 1 & \\
\hline OCB & Pearson Correlation & $.829^{* *}$ & \\
\hline
\end{tabular}


KEY

W C: Working Condition, OCB: Organizational Citizenship Behaviour

\subsubsection{Assumption of Normality}

The test of assumption of normality was done using the variables of the study (working conditions and organizational citizenship behavior). Normality was then tested using the Shapiro-Wilk Test. The distribution was considered normal If the Significance value of the Shapiro-Wilk Test is greater than 0.05, the data is normal. If it is below 0.05 , the data significantly deviate from a normal distribution. From the results in table 4.2 below it is indicated that the working conditions and recognition schemes were normally distributed this is because they all had significance level which is less than 0.05 .

Table 4.2: Tests of Normality ${ }^{\mathrm{b}}$

\begin{tabular}{|l|l|c|c|c|c|c|c|}
\hline & & \multicolumn{3}{|c|}{ Kolmogorov-Smirnov $^{\mathrm{a}}$} & \multicolumn{3}{c|}{ Shapiro-Wilk } \\
\cline { 3 - 8 } & & Statistic & $\mathrm{df}$ & Sig. & Statistic & Df & Sig. \\
\hline OCB & Working conditions & .346 & 29 & .000 & .638 & 29 & .000 \\
\hline & $\begin{array}{l}\text { Recognition } \\
\text { schemes }\end{array}$ & .533 & 35 & .000 & .317 & 35 & .000 \\
\hline
\end{tabular}

\subsection{Model Summary}

From the results on model summary as shown in table $4.3, \mathrm{R}=0.924$, $\mathrm{R}$ - square $=0.853$, adjusted $\mathrm{R}$ square $=0.847$, and the $\mathrm{SE}=1.56794$. Multiple correlation $\mathrm{R}$ coefficients indicate the degree of linear relationship of organization citizenship behaviour with all the predictor variables, where as the coefficient of multiple determinations R-square shows the provision of the total variation in organization citizenship behaviour that is explained by the independent variables, work condition in the regression equation. The R-square gives us the coefficient of determination between the variables the results from the regression analysis give an $\mathrm{R}$-square value of 0.853 , which means that $85.3 \%$ of the independent variables cause the change on dependant variable (organization citizenship behaviour).

Table 4.3: Model Summary

\begin{tabular}{|l|l|l|l|l|}
\hline Model & R & R Square & Adjusted R Square & Std. Error of the Estimate \\
\hline 1 & $.924^{\mathrm{a}}$ & .853 & .847 & 1.56794 \\
\hline
\end{tabular}

4.2.3.5. Analysis of Variance (ANOVA)

The significance of the regression model was tested using Analysis of Variance (ANOVA) which provides information about levels of variability within the regression ANOVA shows the importance of the relationship between the independent and the dependent variables Table 4.4 presents the results of this test.

Table 4.4: Analysis of Variance (ANOVA)

\begin{tabular}{|l|l|r|r|r|r|c|}
\hline \multicolumn{2}{|l|}{ Model } & Sum of Squares & df & Mean Square & F & Sig. \\
\hline \multirow{3}{*}{1} & Regression & 1258.130 & 4 & 314.532 & 127.939 & $.000^{\mathrm{a}}$ \\
\cline { 2 - 7 } & Residual & 216.343 & 88 & 2.458 & & \\
\cline { 2 - 7 } & Total & \multicolumn{2}{|c|}{9} & & & \\
\hline
\end{tabular}

As shown from the table4.4 above, $\mathrm{F}=127.939, \mathrm{p}<0.000$

One way ANOVA was used to test for preferences differences among the variables for $5 \%$ levels of significant in predicting how working condition affected organization citizenship behavior. The $\mathrm{F}$ test provides an overall test of significance of the fitted regression model. The $\mathrm{F}$ value of 127.939 indicates that all the variables in the equation are important hence the overall regression is significant.

Table 4.5: Regression Coefficient

\begin{tabular}{|l|l|l|l|l|l|l|}
\hline \multicolumn{2}{|l|}{ Model } & \multicolumn{2}{l|}{ Unstandardized Coefficients } & $\begin{array}{l}\text { Standardized } \\
\text { Coefficients }\end{array}$ & T & Sig. \\
\cline { 3 - 6 } \multicolumn{2}{l|}{} & B & Std. Error & Beta & \\
\hline \multirow{2}{*}{1} & (Constant) & .128 & .130 & & -.251 & .803 \\
\cline { 2 - 5 } & $\begin{array}{l}\text { Working } \\
\text { conditions }\end{array}$ & .202 & .040 & .165 & 5.072 & .000 \\
\hline
\end{tabular}

The regression equation used to link the dependent and independent variable was as follows; $\mathrm{Y}=\mathrm{b}_{0}+\mathrm{b}_{1} \mathrm{X}_{1}+\varepsilon$ $\mathrm{Y}=-0.128+0.083 \mathrm{X}_{1}+\varepsilon$ 
Where $\mathrm{y}=$ organization citizenship behaviour

$\mathrm{X}_{1}=$ working condition

The coefficients in table 4.5 indicate the corresponding change in the dependent variable when a change of one unit is effected in the independent variable. Thus, a 1\% improvement of working conditions would lead to a $16.5 \%$ organization citizenship behavior.

\section{Conclusion}

From the study it was concluded that Working Condition is a predictor variable in ensuring Organization Citizenship Behaviour, it provides a conducive environment for work, it prioritizes health and safety in the work place, it manages stress in the work place, Working conditions facilitates employee relations, quality of work, $\mathrm{f}$ work life balance and a typical and precarious working environment.

\subsection{Recommendation of the Study}

Based on the findings of this study, it was recommended that Barclays bank should ensure good working conditions at the workplace which would increase the degree of job satisfaction, effectual human resource management and preserving progressive work environment which would affect job satisfaction and organizational performance.

\section{Refference}

[1] Andrew, S (2004). "Job security and crossover of burnout in married couples". Journal of Organizational Behavior, 22, 467-481.

[2] Arul P, (2009). "Organizational citizenship behavior: Construct redefinition, measurement, and validation". Academy of Management Journal, 37, 765-802.

[3] Bagraim et al. (2007). Resistance to Organizational Change: The Role of Cognitive and Affective Processes. Leadership \& Organization Development Journal, Vol. 22, No. 8, 2001, pp. 372-382.

[4] Barclays bank of Kenya, (2015). "Issues that matter to international businesses". A quarterly newsletter ,Barclays Financial Institutions Group -Banks team newsletter

[5] Beach, T (2007) "Job security: A literature review". SALTSA—Joint Programme for working life research in Europe, Report No 1, $1-30$.

[6] Becker, J, (2003). "Content, Causes, and Consequences of Job security: A Theory-Based Measure and Substantive Test." Academy of Management Journal, 32, 803-829.

[7] Benjamin, A. (2012). The Influence of Affective Commitment on Citizenship Behavior and Intention to Quit among Commercial Banks' Employees in Nigeria. Journal of Management and sustainability, 2(2), 54-68.

[8] Bennett S, Paina L, Kim C, Agyepong I, Chunharas S, (2000). Development of measure of work place "deviance”. Journal of Applied Psychology, 85, 349-360

[9] Berge W. (2008) "A control theory of the job stress process". In C. L. Cooper (Ed.), Theories of Organizational Stress (ppp. 153169). Oxford: University Press

[10] Bernstein,Douglas; Penner, Louis A, (2011). Essentials of psychology. Belmont, CA: Wadsworth

[11] Blau, G., Tatum, D. S., McCoy, K., Dobria, L., and Ward-Cook, K. (2004). "Job loss, human capital job feature, and work condition job feature as distinct job insecurity constructs". Journal of Allied Health, 33, 31-41.

[12] Bordia, J. (2004). "Uncertainty during organizational change: Is it all about control"? European Journal of Work and Organizational Psychology, 13, 345-365.

[13] Borman, W.C. (2004). The Concept of Organizational Citizenship. Personnel Decisions Research Institutes, Inc., Tampa, Florida, and University Of South Florida.

[14] Bowen, B.B, (2000). Recognizing and rewarding employees, Mcgraw-Hill.

[15] Broad, A (2007). Impact of Reward and Recognition on Job security and Motivation: An Empirical Study from Pakistan. International Journal of Business and Management, Vol. 5, No. 2, pp.159

[16] Cannel, P (2008) Job security in managers: Antecedents and consequences. Journal of Organizational Behavior, 14, 617-630.

[17] Central bank of Kenya (2012). Annual reports and financial statements.

[18] Christina, Stamper \& Lyn Van Dyne, (2003) “Organizational Cirizenship: A Comparison Between Part time and Full time Service Employee”, Cornell Hotel and Restaurant Administration Quarterly, no. 44, pp. 33-44

[19] Colarelli, M, (2006). "A typology of deviant workplace behaviors: A multi-dimensional scaling study". Academy of Management Journal, 38, 555-572.

[20] Coles, O (2002). The impact of perceived work environment on Job security of hospital staff nurses, College of Nursing, University of North Carolina, Medline, 7, 84-90

[21] Condly, et al, (2003). The Effects of Incentives on Performance ImprovementQuarterly, 16(3), 46-63

Work place Performance: A Meta-analytic Review of Research Studies.

[22] Dalal, R. S, (2005). "A meta-analysis of the relationship between organizational citizenship behavior and counterproductive work behavior". Journal of Applied Psychology, 90, 1241-1255.

[23] Dalal, S. (2005). "A meta-analysis of the relationship between organizational citizenship behavior and counterproductive work behavior". Journal of Applied Psychology, 90, 1241-1255.

[24] Dekker, et al (2002). Obstacles to Effective Organizational Change. Leadership \& Organization Development Journal, Vol. 23, No. 1, 2002, pp. 6-15.

[25] Dessler (2010) Rewarding employee loyalty: an organizational justice approach. Int. J. Org. Behav. 8(3).

[26] Devries, M, (2009). Collective and Individual Improvement Activities: The Role of Reward Systems. Personnel Review, Vol. 31, No.3, 2002, pp. 320-337.

[27] Droar, D. (2006). Expectancy theory of motivation. Retrieved October 2, 2010

[28] Ellis, et al (2007). Job Attitude Scale (unpublished), Department of Psychology, Banaras Hindu University.

[29] Elstad, E, (2011) "Social exchange theory as an explanation of organizational citizenship behaviour among teachers". International Journal of Leadership 
[30] Farh J., Zhong C., \& Organ D. W. (2004). Organizational citizenship behaviour in the People's Republic of China. Organization Science $15(2)$

[31] Feather, N. T. , and Rauter, K. A ,(2004). “Organizational citizenship behaviours in relation to job status, job insecurity, organizational commitment and identification, job satisfaction and work values". Journal of Occupational and Organizational Psychology, 77, 81-94.

[32] Fox, S., Spector, E. P., \& Miles, D. (2001). Counterproductive Work Behavior (Cwb) In Response to Job Stressors and Organizational Justice: Some Mediator and Moderator Tests For Autonomy And Emotions. Journal of Vocational Behavior, 59, 291-309.

[33] Griffin, R (2002). Management, Boston Houghton Mifflin Co.

[34] Gunlu, A (2010). Performance Appraisal Scale (unpublished), Department of Psychology, Banaras Hindu University.

[35] Guyo, A. G. \& Guyo, W (2014). Role of reward and performance management in development of organizational citizenship behaviour among the civil servants in Kenya. International Journal of Social Sciences and Entrepreneurship, 1 (12), 802-830.

[36] Haines, N. (2002). Collective and Individual Improvement Activities: The Role of Reward Systems. Personnel Review, Vol. 31, No.3, 2002, pp. 320-337.

[37] Hockenbury RT and Sammarco GJ (2003) "Development and validation of the Job Security Index and the Job Security Satisfaction Scale: A classical test theory and IRT approach”. Journal of Occupational and Organizational Psychology, 76, 451-467.

[38] Hockenbury, D, (2003) Psychology. New York: Worth Publishers

[39] Jacqueline A-M., Shapiro, C., Kessler, I., and Purcell, J. (2004) Exploring Organizationally Directed Citizenship Behavior: Reciprocity or 'It'S My Job'? Journal of Management Studies, 41:1, 0022-2380

[40] Judge, T. A., Scott, B. A., and Ilies, R, (2006) "Hostility, job attitudes, and workplace deviance: Test of a multilevel model". Journal of Applied Psychology, 91, 126-138.

[41] Kelloway, E. K., Loughlin, C., Barling, J., \& Nault, A. (2002) Self Reported Counter Productive Behavior And Organizational Citizenship Behaviors: Separate But Related Constructs, International Journal of Selection and Assessment, Vol. 10, No. 1/2.

[42] Knowles's (1990) theory of adult learning or Andragogy

[43] Lawler, E. (2000) Rewarding excellence: Pay strategies for the new economy. Jossey-Bass, San Francisco.

[44] Mahfuz J, (2012) Examining the Relationship between Organizational Justice, Job Security, and Organizational Citizenship Behavior in the Jordanian Banks: A Structural Equation Modeling Perspective

[45] McNamara, S (2008). Improving Safety by the Modification of Behavior. Construction Management and Economics, Vol. 12, No. 1, 1994, pp. 67-78.

[46] Mugenda, M. (2003) .Research Methods Quantitative and Qualitative Approaches. Act Press Nairobi, Kenya

[47] Nickson, Warhurst D and Hurrell (2008) Stress Management Well-Being and Job Satisfaction. In Werner A (Ed.), Organizational Behaviour a Contemporary South African Perspective, 2nd ed. Pretoria: Van Schaik.

[48] Organ and Dennis W (2006) Organizational Citizenship Behavior. Its Nature, Antecendents, and Consequences. California: Sage Publications, Inc.

[49] Oso, Y. and Onen, D. (2005) A general Guide to Writing Research Thesis and Report. Kisumu: Options Printers and Publishers

[50] Paille P. (2009) Assessing Organizational Citizenship Behaviour in the French Context: Evidence for the Four-Dimensional Model.The Journal of Psychology 143.

[51] Pantja D and Sundring, (2005).’Pengaruh Organizational Citizenship Behavior terhadap Persepsi Kualitas Karyawan dan Dampaknya pada Kepercayaan Konsumen Bidang jasa di Surabaya ”, Accounting and Management Journal Widya Mandala University, vol 5 (2), p 236-247.

[52] Peterson, A.. (2002) Handbook of noise measurement. New Concord, Mass

[53] Podsakoff P. M., MacKenzie S. B,. Paine J. B. \& Bachrach D. G. (2000) Organizational citizenship behaviour: A critical review of the theoretical and empirical literature and suggestions for future research. Journal of Management 26.

[54] Podsakoff, N. P. (2003) "Common method biases in behavioral research: A critical review of the literature and recommended remedies". Journal of Applied Psychology, 88, 879-903.

[55] Reisel, W. D., Probst, T. M., Chia, S-L., Maloles, C. M., \& König, C. J, (2010). The effects of job insecurity on job satisfaction, organizational citizenship behavior, deviant behavior, and negative emotions of employees.International Studies of Management and Organization, 40(1), 74-91.

[56] Price water coopers report (2011).Growth of banking sector in kenya

[57] Rioux S. M. \& Penner L. A. (2001) The causes of organizational citizenship behaviour: a motivational analysis. Journal of applied Psychology.

[58] Deci , E. L. Ryan , R. M.(2000) The"what" and "why"of goal pursuits: Human needs and the self-determination of behavior. PsychologicalInquiry11227-268SALTSA Joint Programme for working life research in Europe, Report No 1, 1-

[59] Sofiah, K.K., Padmashantini,P.,Gengeswari,K (2014) A Study On Organizational Citizenship Behavior In Banking Industry, International Journal for Innovation Education and Research

[60] Teo, E. (2005b) Framework for Project Managers to Manage Construction Safety. International Journal of Project Management, Vol. 23, No. 4, 2005.

[61] Waterloo, ON, CA, (2009). The Relationship between Rewards and Recognition, Service-Oriented Organizational Citizenship Behaviour, and Customer Satisfaction

[62] Wright GB, Seidman JG and Seidman CE. (2001).Leadership training in organizational justice to increase citizenship behaviour within a labor union: A replication. Personnel Psychology

[63] Yoon, M.H., and Suh, J., (2003) "Organizational citizenship behaviors and service quality as external effectiveness of contact employees", Journal of Businees Research 56 p. 597-611. 